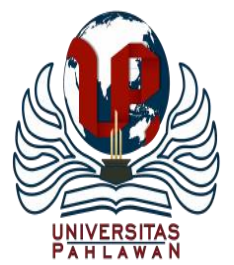

Edukatif : Jurnal Ilmu Pendidikan Volume 3 Nomor 4 Tahun 2021 Halm 1757 - 1764

EDUKATIF: JURNAL ILMU PENDIDIKAN

Research \& Learning in Education

https://edukatif.org/index.php/edukatif/index

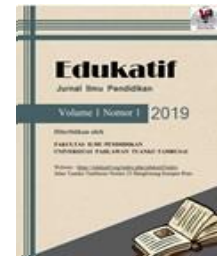

\title{
Hubungan Antara Kontrol Diri Dan Dukungan Sosial Orangtua Dengan Keberhasilan Keluarga Pada Pernikahan Usia Dini Di Kota Padang
}

\author{
Dedi Kurniawan $^{1 \bowtie}$, A. Muri Yusuf ${ }^{2}$ \\ Universitas Negeri Padang, Indonesia ${ }^{1,2}$ \\ E-mail : $\underline{\text { kurniawandedi264@gmail.com }}^{1}$, yusufmuri7@ gmail.com ${ }^{2}$
}

\begin{abstract}
Abstrak
Penelitian ini bertujuan untuk menguji hubungan antara kontrol diri dan dukungan orangtua dengan keberhasilan keluarga pada pernikahan usia dini di kota Padang. Jenis penelitian merupakan penelitian kuantitatif dengan menggunakan pendekatan deskriptif korelasional. Penelitian ini menggunakan teknis analisis regresi ganda yang bertujuan untuk menguji hubungan dua variabel bebas terhadap satu variabel terikat. Adapun variabel dalam penelitian ini terdiri dari kontrol diri $\left(\mathrm{X}_{1}\right)$ dan dukungan orangtua $\left(\mathrm{X}_{2}\right)$ yang merupakan variabel bebas, serta keberhasilan keluarga pada pernikahan usia dini (Y) merupakan variabel terikat. Penelitian ini dilaksanakan di Kota Padang, Provinsi Sumatera Barat. Populasi penelitian ini adalah pasangan yang menikah pada usia dini di Kota Padang berjumlah 136 orang. bahwa anggota masyarakat yang menjadi estimasi populasi penelitian berjumlah 90 orang. Pengambilan sampel ditetapkan untuk mencapai tujuan penelitian yang telah dirumuskan. Untuk menentukan besarnya sampel dengan menggunakan rumus Slovin. Data teknis analisis dalam penelitian ini menggunakan statistik parametrik yaitu teknik analisis ANOVA (Analysis of Variance). Hasil Penelitian ini menunjukkan bahwa kontrol diri dan dukungan sosial orangtua secara bersama-sama berkontribusi signifikan terhadap keberhasilan keluarga pada pernikahan usia dini.
\end{abstract}

Kata Kunci: kontrol diri, dukungan sosial orangtua, dan keberhasilan keluarga pada pernikahan usia dini.

\begin{abstract}
This study aims to examine the relationship between self-control and parental support with family success in early marriage in the city of Padang. This type of research is quantitative research using a descriptive correlational approach. This study uses the multiple regression analysis technique which aims to examine the relationship between two independent variables to one dependent variable. The variables in this study consisted of self-control (X1) and parental support (X2) which were independent variables, and family success in early marriage $(Y)$ was the dependent variable. This research was conducted in Padang City, West Sumatra Province. The population of this study was couples who married at an early age in the city of Padang totaling 136 people that the community members who make up the estimated population of the study are 90 people. Sampling is determined to achieve the research objectives that have been formulated. To determine the sample size using the Slovin formula. Technical data analysis in this study uses parametric statistics, namely the ANOVA (Analysis of Variance) analysis technique. The results of this study indicate that self-control and parental social support together contribute significantly to family success in early marriage.
\end{abstract}

Keywords: self control, Parental Social Support, Family Success in Early Marriage

Copyright (c) 2021 Dedi Kurniawan, A. Muri Yusuf

Corresponding author:

Email : kurniawandedi264@gmail.com

DOI : https://doi.org/10.31004/edukatif.v3i4.680

ISSN 2656-8063 (Media Cetak)

ISSN 2656-8071 (Media Online)

Edukatif : Jurnal Ilmu Pendidikan Vol 3 No 4 Tahun 2021 p-ISSN 2656-8063 e-ISSN 2656-8071 
1758 Hubungan Antara Kontrol Diri Dan Dukungan Sosial Orangtua Dengan Keberhasilan Keluarga Pada Pernikahan Usia Dini Di Kota Padang - Dedi Kurniawan, A. Muri Yusuf

DOI: https://doi.org/10.31004/edukatif.v3i4.680

\section{PENDAHULUAN}

Manusia adalah makhluk sosial manusia akan selalu ketergantungan dengan manusia lainnya, salah satu bentuk ikatan sosial yang erat ialah sebuah pernikahan. Pernikahan merupakan salah satu hal penting yang akan dihadapi oleh setiap manusia dalam perjalanan hidup dan ikatan lahir batin antara seorang pria dan seorang wanita sebagai suami istri dengan tujuan membentuk keluarga (Walgito, 2002). Ketika membina keluarga terkadang pasangan suami istri belum mempunyai pondasi yang kuat, sehingga terjadi ketidakharmonisan dalam rumah tangga. Salah satu penyebab terjadinya permasalahan dalam rumah tangga adalah pernikahan di usia dini. Tugas perkembangan yang harus dilakukan oleh individu yang berada pada masa remaja atau usia dini adalah berkenaan dengan kehidupan berkeluarga (Ali \& Ashori, 2012). Beberapa permasalahan dalam pernikahan usia dini meliputi terjadinya kekerasan dalam rumah tangga (Afdal, 2015), dampak terhadap kesehatan reproduksi (Djamilah \& Kartikawati, 2014), anak yang dilahirkan dan kesehatan psikologi anak, serta tinjauan hukum terkait dengan pernikahan anak (Fadlyana \& Larasaty, 2016).

United Nations Fund for Population Activities (UNFPA) sebagai organisasi PBB bidang populasi, memperkirakan pada tahun 2030 diperkirakan pertahunnya mencapai 15,1 juta. Berdasarkan data yang dikutip sindonews.com dari Badan Pusat Statistik (BPS), pada Selasa 16 April 2019 terdapat angka persentase pernikahan dini di usia 16 tahun atau kurang di Indonesia meningkat menjadi 15,66\% di tahun 2018, dibanding tahun sebelumnya $14,18 \%$. di Propinsi Sumatra Barat, berdasarkan data yang dikutip republika.co.id dari catatan Lembaga Pengkajian dan Pemberdayaan Masyarakat (LP2M) Sumatra Barat yang mengacu pada data Badan Kependudukan dan Keluarga Berencana Nasional (BKKBN), pada Selasa 24 Juli 2018 bahwasanya sepanjang 2010 hingga 2015 terjadi pernikahan usia dini (di bawah 18 tahun) sebanyak 6.083 pasangan (Prila, 2017).

Pernikahan usia dini secara faktual memiliki banyak dampak negatif. Pernikahan usia dini mempengaruhi secara negatif masa depan perempuan, karena pernikahan dini akan membatasi gerak sang perempuan, membuat mereka tak punya kesempatan melakukan berbagai hal yang seharusnya mereka lakukan pada usia tersebut. Terdapat $33.5 \%$ perempuan yang menikah pada usia dini, hanya sekitar $5.6 \%$ yang masih melanjutkan pendidikannya (Alfa, 2019). Hal ini sesuai dengan penelitian yang dilakukan Jensen and Thornton bahwa wanita yang menikah muda yang kurang perhatian orangtua cenderung kurang memiliki pendidikan dan mulai mengasuh anak lebih awal, dan memiliki lebih sedikit kekuatan pengambilan keputusan dalam rumah tangga. Mereka juga lebih mungkin mengalami kekerasan dalam rumah tangga (Jensen \& Thornton, 2003).

Kontrol diri merupakan suatu perisai dalam membentengi diri dari hal negatif yang dapat merusak pola pikir diri seorang remaja (Pratiwi, 2004). Kontrol perilaku yang baik maka akan dapat menyesuaikan dirinya dengan baik saat menghadapi pernikahan. Penyesuaian pernikahan menuntut adanya kematangan dan tumbuh serta berkembangnya pengertian diantara pasangan (Hassan, 2005).

Dukungan sosial orangtua menentukan remaja untuk mengambil keputusan menjalani pernikahan di usia dini dan orangtua juga memiliki peran dalam penundaan usia pernikahan anak (Wulanuari \& Napida, 2017). Hubungan komunikasi yang baik antara orang tua dengan anak akan menciptakan saling memahami terhadap masalah-masalah keluarga, khususnya mengenai problematika remaja sehingga dapat berpengaruh terhadap sikap, perilaku maupun pandangan yang dibawa anak sesuai dengan nilai-nilai yang ditanamkan kepada anak oleh orang tua mereka (Davis, 2007). Dengan demikian, dapat dikatakan bahwa dukungan orangtua beperan penting terhadap kehidupan anak. Kenyataan tentang pentingnya dukungan orangtua inilah yang kemudian dapat memberikan pemahaman yang baik kepada anak dalam hal ini tentang pernikahan, dimana orangtua dapat memberikan hal-hal yang berkaitan dalam pernikahan secara menyeluruh sehingga anak dapat mempunyai pengetahuan dan mengimplementasiakan dalam menjalani pernikahan Penelitian ini merupakan penelitian pertama mengenai hubungan antara kontrol diri dan dukungan sosial orangtua dengan 
1759 Hubungan Antara Kontrol Diri Dan Dukungan Sosial Orangtua Dengan Keberhasilan Keluarga Pada Pernikahan Usia Dini Di Kota Padang - Dedi Kurniawan, A. Muri Yusuf

DOI: https://doi.org/10.31004/edukatif.v3i4.680

keberhasilan keluarga pada pernikahan usia dini di kota Padang, dengan harapan penelitian ini menjadi sumber referensi bagi pasangan yang menjalani pernikahan usia dini.

\section{METODE PENELITIAN}

Penelitian ini merupakan penelitian kuantitatif dengan menggunakan pendekatan deskriptif korelasional. Penelitian ini menggunakan teknis analisis regresi ganda yang bertujuan untuk menguji hubungan dua variabel bebas terhadap satu variabel terikat. Adapun variabel dalam penelitian ini terdiri dari kontrol diri $\left(\mathrm{X}_{1}\right)$ dan dukungan orangtua $\left(\mathrm{X}_{2}\right)$ yang merupakan variabel bebas, serta keberhasilan keluarga pada pernikahan usia dini (Y) merupakan variabel terikat. Penelitian ini dilaksanakan di Kota Padang, Provinsi Sumatera Barat. Populasi penelitian ini adalah wanita yang menikah pada usia dini di Kota Padang berjumlah 90 orang. bahwa anggota masyarakat yang menjadi estimasi populasi penelitian berjumlah 90 orang..Pengambilan sampel ditetapkan untuk mencapai tujuan penelitian yang telah dirumuskan. Untuk menentukan besarnya sampel dengan menggunakan rumus Slovin (Yusuf, 2014), sebagi berikut.

Keterangan: $\mathrm{s}=$ jumlah sampel

$$
\mathrm{s}=\frac{\mathrm{N}}{1+\mathrm{N} \cdot \mathrm{e}^{2}}
$$

$$
\begin{aligned}
& \mathrm{N}=\text { jumlah populasi } \\
& \mathrm{e}=(0,05) \text { derajat ketelitian atau nilai kritis yang diinginkan. }
\end{aligned}
$$

Jadi, besar sampel yang diambil adalah:

$$
\begin{aligned}
& \mathrm{S}=\frac{N}{1+N(\mathrm{e})^{2}} \\
& \mathrm{~s}=\frac{90}{1+90(0,05)^{2}} \\
& \mathrm{~s}=\frac{90}{1+90 \times 0,0025} \\
& \mathrm{~S}=\frac{90}{1+0,225} \\
& \mathrm{~s}=\frac{90}{1} \\
& \mathrm{~S}=90
\end{aligned}
$$

Pengambilan jumlah sampel di ambil dengan menggunakan rumus sebagai berikut (Prasetyo \& Jannah, 2008). Sampel $=\frac{\text { Jumlah anggota }}{\text { Populasi }} \times$ Total Sampel. Data Sampel disajikan dan di distribusikan distribusikan kedalam tabel sebagai berikut.

KUA Padang Barat

KUA Padang Timur

KUA Padang Utara

KUA Padang Selatan

KUA Pauh

KUA Kuranji

KUA Lubuk Kilangan

KUA Lubuk Begalung

KUA Bungus Teluk Kabung

KUA Koto Tangah

KUA Nanggalo

$$
\begin{array}{ll}
: & \text { Sampel }=\frac{7}{90} \times 90=7 \\
: & \text { Sampel }=\frac{5}{90} \times 90=5 \\
: & \text { Sampel }=\frac{5}{90} \times 90=5 \\
: & \text { Sampel }=\frac{9}{90} \times 90=9 \\
: & \text { Sampel }=\frac{8}{90} \times 90=8 \\
: & \text { Sampel }=\frac{7}{90} \times 90=7 \\
: & \text { Sampel }=\frac{9}{90} \times 90=9 \\
: & \text { Sampel }=\frac{7}{90} \times 90=7 \\
: & \text { Sampel }=\frac{10}{90} \times 90=10 \\
: & \text { Sampel }=\frac{14}{90} \times 90=14 \\
: & \text { Sampel }=\frac{9}{90} \times 90=9
\end{array}
$$


1760 Hubungan Antara Kontrol Diri Dan Dukungan Sosial Orangtua Dengan Keberhasilan Keluarga Pada Pernikahan Usia Dini Di Kota Padang - Dedi Kurniawan, A. Muri Yusuf

DOI: https://doi.org/10.31004/edukatif.v3i4.680

\section{HASIL DAN PEMBAHASAN PENELITIAN}

Kategori tingkat dukungan sosial orangtua dan kontrol diri dalam keberhasilan keluarga pada pernikahan usia dini di Padang secara keseluruhan dapat dilihat pada tabel di bawah ini.

Tabel 1

Distribusi Frekuensi dan Presentase Kontrol diri (n=90)

\begin{tabular}{|c|c|c|c|c|c|}
\hline $\begin{array}{c}\text { Jenis } \\
\text { Kelamin }\end{array}$ & Kategori & Interval Skor & Frekuensi & $\%$ & Mean \\
\hline \multirow{5}{*}{ Wanita } & Sangat Tinggi (ST) & $123-145$ & 12 & 13.3 & \multirow{6}{*}{106,3} \\
\hline & Tinggi (T) & $100-122$ & 44 & 48.9 & \\
\hline & Sedang (S) & $77-99$ & 29 & 32.2 & \\
\hline & Rendah (R) & $54-75$ & 4 & 4.4 & \\
\hline & Sangat Rendah (SR) & $\leq 53$ & 1 & 1.1 & \\
\hline & Jumlah & & 60 & 100 & \\
\hline
\end{tabular}

Berdasarkan tabel diatas memperlihatkan tentang jumlah keseluruhan sampel penelitian sebanyak 90 orang wanita yang menikah pada usia dini. Rata-rata wanita yang menikah pada usia dini memiliki tingkat kontrol diri yang tinggi dengan nilai mean sebesar 106,3 secara mayoritas ada 44 orang berada pada kategori tinggi dengan persentase $30,3 \%$, selebihnya 29 orang berada pada kategori sedang yaitu $20 \%$, kemudian pada kategori sangat tinggi yaitu 12 orang dengan persentase $8,3 \%$, pada kategori sangat rendah yaitu 4 orang dengan persentase $6,7 \%$ dan kategori sangat rendah yaitu 1 orang dengan persentase $1,7 \%$.

Tabel 2

Distribusi Frekuensi dan Dukungan Sosial Orangtua(n = 90)

\begin{tabular}{clcccc}
\hline $\begin{array}{c}\text { Jenis } \\
\text { Kelamin }\end{array}$ & \multicolumn{1}{c}{ Kategori } & $\begin{array}{c}\text { Interval } \\
\text { skor }\end{array}$ & Frekuensi & \% & Mean \\
\hline \multirow{5}{*}{ Wanita } & Sangat Tinggi (ST) & $110-130$ & 33 & 36.7 \\
\cline { 2 - 5 } & Tinggi (T) & $89-109$ & 41 & 45.6 & \\
\cline { 2 - 5 } & Sedang (S) & $68-88$ & 13 & 14.4 & \multirow{2}{*}{104,5} \\
\cline { 2 - 5 } & Rendah (R) & $47-67$ & 2 & 2.2 & \\
\cline { 2 - 5 } & Sangat Rendah (SR) & $\leq 26$ & 1 & 1.1 \\
\hline
\end{tabular}

Tabel diatas memperlihatkan tentang jumlah keseluruhan sampel penelitian sebanyak 90 orang wanita yang menikah pada usia dini. Rata-rata wanita yang menikah pada usia dini memiliki tingkat dukungan sosial orangtua dengan nilai mean sebesar 104,5, secara mayoritas ada 41 orang berada pada kategori tinggi dengan persentase $45,6 \%$, selebihnya 33 orang berada pada kategori sangat tinggi yaitu 36,7\%, kemudian pada kategori sedang yaitu 13 orang dengan persentase $14,4 \%$, pada kategori rendah yaitu 2 orang dengan persentase 2,2\% dan kategori sangat rendah yaitu 1 orang dengan persentase $1,1 \%$.

Hasil pengumpulan dan pengolahan data melalui instrumen keberhasilan keluarga pada pernikahan usia dini dari keseluruhan sampel (responden) berjumlah 90 orang wanita yang menikah pada usia dini, dapat dilihat pada Tabel 3 di bawah ini. 
1761 Hubungan Antara Kontrol Diri Dan Dukungan Sosial Orangtua Dengan Keberhasilan Keluarga Pada Pernikahan Usia Dini Di Kota Padang - Dedi Kurniawan, A. Muri Yusuf

DOI: https://doi.org/10.31004/edukatif.v3i4.680

Tabel 3

Distribusi Frekuensi dan Keberhasilan Keluarga Pada Pernikahan Usia Dini (n= 90)

\begin{tabular}{clcccc}
\hline \multirow{2}{*}{$\begin{array}{c}\text { Jenis } \\
\text { Kelamin }\end{array}$} & \multicolumn{1}{c}{ Kategori } & $\begin{array}{c}\text { Interval } \\
\text { Skor }\end{array}$ & $\begin{array}{c}\text { Frekuens } \\
\mathbf{i}\end{array}$ & \% & \multirow{2}{*}{ Mean } \\
\hline \multirow{5}{*}{ Wanita } & Sangat Tinggi (ST) & $169-200$ & 10 & 11.1 \\
\cline { 2 - 5 } & Tinggi (T) & $137-168$ & 55 & 61.1 \\
\cline { 2 - 5 } & Sedang (S) & $105-136$ & 22 & 24.4 & \multirow{2}{*}{149,2} \\
\cline { 2 - 5 } & Rendah (R) & $73-104$ & 2 & 2.2 & \\
\cline { 2 - 5 } & Sangat Rendah (SR) & $\leq 41$ & 1 & 1.1 \\
\hline
\end{tabular}

Tabel di atas, memperlihatkan tentang jumlah keseluruhan sampel penelitian sebanyak 90 orang wanita yang menikah pada usia dini. Rata-rata wanita yang menikah pada usia dini memiliki tingkat keberhasilan keluarga pada pernikahan usia dini dengan nilai mean sebesar 149,2, secara mayoritas ada 55 orang berada pada kategori tinggi dengan persentase $61,1 \%$, selebihnya 22 orang berada pada kategori sedang yaitu $24,4 \%$, kemudian pada kategori sangat tinggi yaitu 10 orang dengan persentase $11,1 \%$, pada kategori rendah yaitu 2 orang dengan persentase $2,2 \%$ dan kategori sangat rendah yaitu 1 orang dengan persentase $1,1 \%$. Data keberhasilan keluarga pada pernikahan usia dini berdasarkan aspek dapat dilihat pada tabel di bawah ini.

Tabel 4

Aspek Keberhasilan Keluarga pada Pernikahan Usia Dini

\begin{tabular}{|c|c|c|c|c|c|c|c|c|}
\hline No & Aspek & $\begin{array}{l}\text { Jenis } \\
\text { Kelamin }\end{array}$ & Max & Min & Mean & SD & $\%$ & Kategori \\
\hline 1 & $\begin{array}{l}\text { Kebahagian } \\
\text { Suami Istri }\end{array}$ & Wanita & 55 & 23 & 43,7 & 6,6 & 79,4 & $\mathrm{~T}$ \\
\hline 2 & $\begin{array}{l}\text { Kemampuan } \\
\text { Untuk } \\
\text { Memperoleh } \\
\text { Kepuasan } \\
\text { Dari } \\
\text { Perbedaan } \\
\text { Pendapat }\end{array}$ & Wanita & 40 & 18 & 32,0 & 4,6 & 79,9 & $\mathrm{~T}$ \\
\hline 3 & Kebersamaan & Wanita & 30 & 10 & 26,0 & 3,5 & 86,8 & ST \\
\hline 4 & $\begin{array}{l}\text { Penyesuaian } \\
\text { yang Baik } \\
\text { dalam } \\
\text { Masalah } \\
\text { Keuangan }\end{array}$ & Wanita & 39 & 17 & 27,6 & 4,4 & 69,1 & $\mathrm{~S}$ \\
\hline 5 & $\begin{array}{l}\text { Penyesuaian } \\
\text { yang Baik } \\
\text { dari Pihak } \\
\text { Keluarga } \\
\text { Pasangan }\end{array}$ & Wanita & 29 & 8 & 19,9 & 3,5 & 66,3 & $\mathrm{~S}$ \\
\hline
\end{tabular}


1762 Hubungan Antara Kontrol Diri Dan Dukungan Sosial Orangtua Dengan Keberhasilan Keluarga Pada Pernikahan Usia Dini Di Kota Padang - Dedi Kurniawan, A. Muri Yusuf

DOI: https://doi.org/10.31004/edukatif.v3i4.680

Tabel 4 di atas menunjukkan tentang tingkat keberhasilan keluarga pada pernikahan usia dini pada wanita. Aspek kebahagian suami istri berada pada kategori tinggi dengan persentase 79,4\%, aspek kemampuan untuk memperoleh kepuasan dari perbedaan pendapat berada pada kategori tinggi dengan persentase $79,9 \%$, aspek kebersamaan berada pada kategori sangat tinggi dengan persentase $86,8 \%$, aspek penyesuaian yang baik dalam masalah keuangan berada pada kategori sedang dengan persentase $69,1 \%$, dan penyesuaian yang baik dari pihak keluarga pasangan berada pada kategori sedang dengan persentase $66,3 \%$.

Langkah berikutnya dilaksanakan pengujian terhadap hipotesis penelitian. Hipotesis dalam penelitian ini, adalah sebagai berikut. Kontrol Diri $\left(\mathrm{X}_{1}\right)$ dan Dukungan Sosial Orangtua $\left(\mathrm{X}_{2}\right)$ dengan Keberhasilan Keluarga pada Pernikahan Usia Dini (Y). pengujian hipotesis dapat disimpulkan hasil penelitian dalam bentuk gambar hubungan dukungan sosial orangtua dan kontrol diri terhadap keberhasilan keluarga pernikahan usia dini dapat dilihat pada gambar 1 .

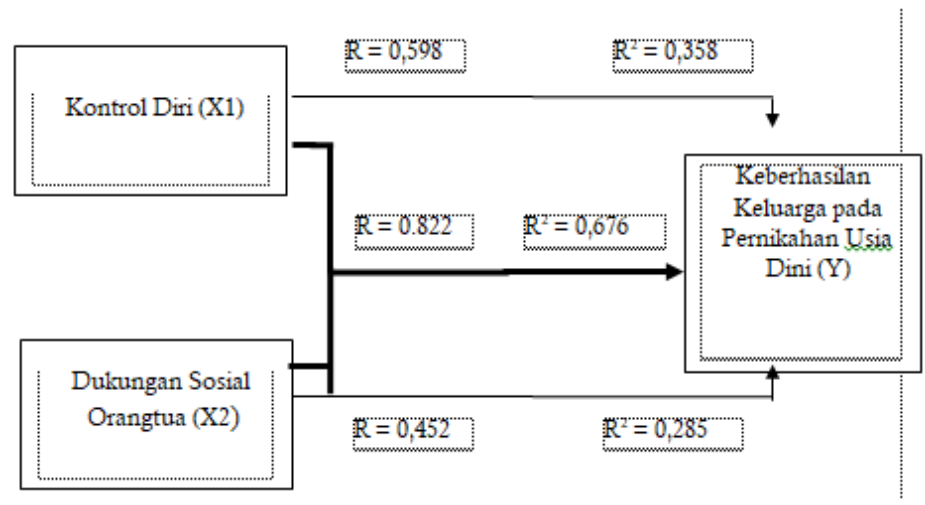

\section{Gambar 1. Hubungan Variabel Kontrol Diri $\left(X_{1}\right)$ dan Dukungan Sosial Orangtua $\left(X_{2}\right)$ dengan Keberhasilan Keluarga pada Pernikahan Usia Dini (Y)}

Gambar diatas menunjukan arah regresi kontrol diri dan dukungan sosial orangtua dengan keberhasilan keluarga pada pernikahan usia dini. Variabel kontrol diri lebih besar memberikan kontribusi dengan keberhasilan keluarga pada pernikahan usia dini dibandingkan dengan variabel dukungan sosial orangtua, akan tetapi secara bersama-sama kedua variabel memberikan hubungan dalam keberhasilan keluarga pada pernikahan usia dini. Berdasarkan pemaparan tersebut dapat memberi arti bahwa tinggi rendahnya keberhasilan keluarga pada pernikahan usia dini yang dijalani oleh wanita. ditentukan oleh tinggi rendahnya masing-masing variabel kontrol diri dan dukungan sosial orangtua. Oleh karena itu, untuk meningkatkan keberhasilan keluarga pada pernikahan usia dini diperlukan tingkat kontrol diri dan dukungan sosial orangtua yang baik.

Hasil penelitian menunjukkan bahwa kontrol diri dan dukungan sosial orangtua secara bersama-sama berkontribusi signifikan terhadap keberhasilan keluarga pada pernikahan usia dini. Temuan ini diperoleh berdasarkan rangkaian analisis data bahwa koefisien regresi sebesar 0,786 Koefisien determinasi (R Square) kontrol diri dan dukungan sosial orangtua secara bersama-sama terhadap keberhasilan keluarga pada pernikahan usia dini adalah sebesar 0,617. Artinya, kontribusi kontrol diri dan dukungan sosial orangtua secara bersama-sama terhadap keberhasilan keluarga pada pernikahan usia dini sebesar $61,7 \%$, sedangkan sisanya dijelaskan oleh variabel lain yang tidak diteliti dalam penelitian ini. Hal tersebut mengungkapkan bahwa kontrol diri dan dukungan sosial orangtua secara bersama-sama dapat menjadi faktor yang berpegaruh terhadap keberhasilan keluarga pada pernikahan usia dini.

Pernikahan pada usia dini menghadapi lebih banyak tantangan dari pada yang menjalani pernikahan biasa. Salah satu permasalahannya ialah belum matangnya pengetahuan tentang pernikahan. Untuk itu perlunya peran dari hal lain agar membantu memudahkan individu yang menjalani pernikahan tersebut, dalam hal ini ialah melalui kontrol diri dan dukungan sosial orangtua. Menurut Ghufron \& Risnawati (2012) kontrol diri merupakan jalinan yang secara utuh yang dilakukan individu terhadap lingkungannya, individu 
1763 Hubungan Antara Kontrol Diri Dan Dukungan Sosial Orangtua Dengan Keberhasilan Keluarga Pada Pernikahan Usia Dini Di Kota Padang - Dedi Kurniawan, A. Muri Yusuf

DOI: https://doi.org/10.31004/edukatif.v3i4.680

dengan kontrol diri tinggi sangat memperhatikan cara-cara yang tepat untuk berperilaku dalam situasi yang bervariasi, Kontrol diri dapat diartikan sebagai kemampuan mengatur proses fisik, psikologis dan perilaku dalam menghadapi stimulus sehingga dapat menghindari konsekuensi yang tidak diinginkan. Kontrol diri memiliki peranan yang sangat penting dalam kehidupan berumah tangga khususnya pada wanita yang menjalani pernikahan usia dini, artinya bahwa dengan kontrol diri yang baik pada individu keberhasilan keluarga pada pernikahan usia dini dapat tercapai dengan baik.

Rook (1985, dalam Smet, 1994) mendefinisikan dukungan sosial sebagai salah satu fungsi hubungan sosial yang menggambarkan tingkat dan kualitas umum dari hubungan interpersonal yang akan melindungi individu dari konsekuensi stres. Dukungan sosial yang diterima dapat membuat individu merasa tenang, diperhatikan, kemudian timbul rasa percaya diri dan kompeten. Tersedianya dukungan sosial akan membuat individu merasa dicintai, dihargai dan menjadi bagian dari kelompok. Dukungan sosial yang diberikan membuat individu lebih percaya diri karena mereka merasa diperhatikan, dirawat, dicintai oleh orang-orang di sekitar mereka, (Nasution, Daharnis, \& Syahniar, 2019). Akan tetapi ketika individu tidak melihat bantuan sebagai bentuk dukungan, dan dukungan yang diberikan tidak sesuai, maka kecil kemungkinan individu dapat keluar dari masalah yang dihadapinya. Rahma (2011) juga mengungkapkan bahwa adanya perasaan didukung oleh lingkungan membuat segala sesuatu menjadi lebih mudah terutama pada waktu menghadapi peristiwa yang menekan. Artinya bahwa dengan adanya dukungan sosial orangtua yang baik terhadap individuu yang menjalani pernikahan usia dini maka tercapai keberhasilan keluarga dengan baik pula.

Berdasarkan penjelasan tersebut, dapat dikatakan bahwa semakin tinggi kontrol diri dan dukungan sosial orangtua maka semakin tinggi tingkat keberhasilan keluarga pada pernikahan usia dini. Untuk itu konselor mempunyai peranan penting dalam upaya meningkatkan keberhasilan keluarga pada pernikahan usia dini dengan cara meningkatkan kontrol diri dan dukungan sosial orangtua pada individu yang sedang menjalani pernikahan usia dini untuk tercapainya keberhasilan keluarga. Upaya tersebut dapat diwujudkan dengan memberikan berbagai pelayanan bimbingan dan konseling. Pelayanan dapat dilakukan secara individual, klasikal maupun kelompok, seperti layanan konseling individual, layanan informasi, layanan bimbingan kelompok dan konseling kelompok dengan program yang disusun. Sejalan dengan penelitian dari Jensen and Thornton (2003) yang berjudul "Early female marriage in the developing world". Wanita yang menikah muda yang kurang perhatian orangtua cenderung kurang memiliki pendidikan dan mulai mengasuh anak lebih awal, dan memiliki lebih sedikit kekuatan pengambilan keputusan dalam rumah tangga. Mereka juga lebih mungkin mengalami kekerasan dalam rumah tangga. Relevansi dengan penelitian ini adalah adanya hubungan antara dukungan orangtua dengan pernikahan usia dini sehingga menyebabkan beberapa permasalahan didalamnya. Keterbatasan penelitian ini ialah jumlah laki-laki yang menikah usia dini jauh lebih sedikit daripada wanita, sehingga ini menyebabkan kurangnya sudut pandang dari laki-laki yang menikah usia dini.dini. Hal ini yang perlu diperhatikan pada penelitian lanjutan agar dapat meneliti tentang laki-laki yang menikah usia dini. Konselor diharapkan mampu memberikan pelayanan konseling terhadap klien yang menjalani pernikahan usia dini yang memiliki kontrol diri yang rendah, dengan cara meningkatkan kontrol diri melalui layanan bimbingan dan konseling dan mengatasi permasalahan klien terkait dengan keberhasilan keluarga pada pernikahan usia dini.

\section{KESIMPULAN}

Kontrol diri dan dukungan sosial orangtua secara bersama-sama mempunyai hubungan yang signifikan dengan keberhasilan keluarga pada pernikahan usia dini. Artinya tinggi atau rendahnya tingkat keberhasilan keluarga pada pernikahan usia dini tidak hanya dipengaruhi satu variabel saja (kontrol diri dan dukungan sosial orangtua), namun dipengaruhi secara bersama-sama oleh kontrol diri dan dukungan sosial orangtua. Hal ini berarti bahwa meningkatnya keberhasilan keluarga pada pernikahan usia dini bisa disebabkan oleh tingkat kontrol diri yang tinggi dan dukungan sosial orangtua yang tinggi. Dengan adanya temuan penelitian ini 
1764 Hubungan Antara Kontrol Diri Dan Dukungan Sosial Orangtua Dengan Keberhasilan Keluarga Pada Pernikahan Usia Dini Di Kota Padang - Dedi Kurniawan, A. Muri Yusuf

DOI: https://doi.org/10.31004/edukatif.v3i4.680

konselor pernikahan hendaknya bisa meningkatkan keberhasilan keluarga pada pernikahan usia dini dengan cara meningkatkan pemahaman kontrol diri dan dukungan sosial orangtua yang baik sehingga diharapkan tercapainya keberhasilan keluarga pada pernikahan usia dini dengan baik.

\section{DAFTAR PUSTAKA}

Afdal, A. (2015). Pemanfaatan Konseling Keluarga Eksperensial untuk Penyelesaian Kasus Kekerasan dalam Rumah Tangga. Jurnal EDUCATIO: Jurnal Pendidikan Indonesia, 1(1).

Alfa, F. R. (2019). pernikahan dini dan perceraian di Indonesia. JAS: Jurnal Ahwal Syakhshiyyah, 1(1), 4956.

Ali, M. dan Asrori, M. (2012). Psikologi Remaja: Perkembangan Peserta Didik. Jakarta: PT Bumi Aksara

Bimo Walgito. 2002. Pengantar Psikologi Umum. Yogyakarta: Andi Offset

Djamilah, D., \& Kartikawati, R. (2014). Dampak Perkawinan Anak di Indonesia. Jurnal Studi Pemuda, 3(1), $1-16$.

Fadlyana, E., \& Larasaty, S. (2016). Pernikahan usia dini dan permasalahannya. Sari Pediatri, 11(2), 136141.

Ghufron, M. N, \& Risnawita, R. (2014). Teori-teori Psikologi. Yogyakarta: Ar- ruzz Media

Hassan, Rienny. (2005). Usia Lima Tahun Perkawinan Rawan. Jurnal Perkawinan Rawan.on-line. Vol 3:8-11.

Jensen, R., \& Thornton, R. (2003). Early female marriage in the developing world. Gender \& Development, 11(2), 9-19. https://doi.org/10.1080/741954311

Nasution, H., Daharnis., \& Syahniar. (2019). Contribution of emotional maturity and social support to selfadjustment of santri in Musthafawiyah Purbabaru Islamic Boarding School. Journal of Educational and Learning Studies, 2(2), 126-134.

Prasetyo, B., \& Jannah, L. M. (2008). Metode Penelitian Kuantitatif. Jakarta: Raja Grafindo Persada.

Prila, I. (2017). Komunikasi Interpersonal Pasangan Pernikahan Usia Dini di Kecamatan Koto Tangah Kota Padang. Universitas Andalas.

Rahma, A. N. (2011). Hubungan efikasi diri dan dukungan sosial dengan penyesuaian diri remaja di panti asuhan. Psikoislamika: Jurnal Psikologi Dan Psikologi Islam, 8(2), 84-93.

Sugiyono. (2012). Metode penelitian pendidikan: Pendekatan kuantitatif kualitatif dan R\&D. Bandung: Alfabeta.

Wulanuari, K. A., \& A, A. N. (2017). Faktor-Faktor yang Berhubungan dengan Pernikahan Dini pada Wanita, $5(1), 68-75$.

Yusuf, A. M. (2014). Metode penelitian: kuantitatif, kualitatif, dan penelitian gabungan. Jakarta: Prenadamedia Group 